Cahiers $d u$ MONDE RUSSE

\section{Cahiers du monde russe}

Russie - Empire russe - Union soviétique et États indépendants

$59 / 4 \mid 2018$

Varia

\title{
ПУТИ ИЗУЧЕНИЯ ЧАСТНЫХ СДЕЛОК XVIII В. В КОНТЕКСТЕ РАЗВИТИЯ « НОВОЙ СОЦИАЛЬНОЙ ИСТОРИИ » ИМПЕРСКОЙ РОССИИ
}

\section{Evgenii Akelev}

\section{OpenEdition \\ Journals}

Édition électronique

URL : https://journals.openedition.org/monderusse/10598

DOI : 10.4000/monderusse. 10598

ISSN : $1777-5388$

Éditeur

Éditions de l'EHESS

Édition imprimée

Date de publication : 1 octobre 2018

Pagination : $575-598$

ISBN : 978-2-7132-2747-9

ISSN : $1252-6576$

\section{Référence électronique}

Evgenii Akelev, «Пути изучения частных сделок XVIII В. В контексте развития « новой социальной истории » имперской России », Cahiers du monde russe [Онлайн], 59/4 | 2018, Выложить онлайн 01 octobre 2018, Наводить справки в 08 janvier 2022. URL: http://journals.openedition.org/ monderusse/10598; DOl: https://doi.org/10.4000/monderusse.10598 
$\begin{array}{ccccccccccccccc}R & \text { U } & \text { S } & \text { S } & \text { I } & \text { E } & & \text { A } & \text { N } & \text { C } & \text { I } & \text { E } & \text { N } & \text { N } & \text { E } \\ & \text { E } & \text { T } & & \text { I } & \text { M } & \text { P } & \text { E } & \text { R } & \text { I } & \text { A } & \text { L } & \text { E } & & \end{array}$

\section{Пути изучения частных сделок XVIII в. в контексте развития «новой социальной истории» имперской России ${ }^{1}$}

KOZLOVA N.V., PROKOF'EVA A.JU., sost.

Dvorjane Moskvy

Svadebnye i duhovnye zaveščanija petrovskogo vremeni

Moskva : ROSSPEN, 2015, 911 p.

KAMENSKIJ A.B.

Rossija v XVIII stoletii : obščestvo i pamjat'

Issledovanija po social'noj istorii i istoričeskoj pamjati

Moskva : Altejja, 2017, 337 p.

ANTONOV A.V., sost.

Opisanie Gramot Kollegii ekonomii

Moskva : Drevlehranilišče, 2016-2018, t.1 : 1194 p. et t. $2: 1394$ p.

В 2008-2016 гг. на страницах журнала «Cahiers du monde russe» была развернута важная дискуссия вокруг базовых классификационных категорий, используемых при осмыслении социальной истории имперской России ${ }^{2}$. В ходе этой дискуссии адекватность и полезность понятий «сословие» и «класс» были поставлены под сомнение, а в качестве актуальной программы для социальных историков была выдвинута разработка новых моделей описания российского общества имперского периода на основе микроанализа реального социального опыта конкретных акторов с особым акцентом на их социальной идентичности и механизмах межгруппового взаимодействия. При этом были отмечены серьезные трудности, которые подстерегают исследователей на этом пути. Так, Элиз Виртшафтер с сожалением отмечает, что историк, обратившись к российским архивам с целью изучить социальную идентичность рядовых российских подданных, обнаружит не столько сведения об их мыслях и чувствах, сколько информацию об их взаимоотношениях с органами власти в изложении чиновников ${ }^{3}$. Не лучше обстоят дела и с источниками о взаимодействии представителей различных социальных групп в повседневной жизни. Как отметил Дэвид Рансел, созданные в органах государственного управления документы предоставляют исследователю не так много возможностей для «анализа отношений между людьми разных социальных статусов», поскольку «Россия управлялась как конгломерат социально обособленных групп», в то время как челобитные и судебно-следственные дела предоставляют информацию о проблемах и конфликтах, но умалчивают о мирном сосуществовании представителей различных социальных групп в обычной повседневной жизни ${ }^{4}$. Источники же личного 
происхождения, подобные дневнику дмитровского купца Ивана Толченова ${ }^{5}$, к сожалению, очень редки.

В данном контексте огромное значение для исследователей социальной истории России XVIII в. приобретают частные акты. Как известно, основной функцией этого источника как раз и является юридическая фиксация самых разнообразных случаев мирного взаимодействия представителей различных социальных групп. Важно отметить, что частные акты почти всегда включают в себя социальные самохарактеристики контрагентов, а также, как правило, предполагают участие нескольких свидетелей и поручителей. Не случайно акты - «излюбленный источник французской социальной истории 1960-х годов» ${ }^{6}$. Н.Е. Копосов даже говорит о «нотариальной эре» во французской историографии, а также полагает, что «если бы не архивы нотариусов, не было бы и спора о классах и сословиях. Ведь задача социальной истории состояла именно в том, чтобы сконструировать модель общества Старого Порядка на основе нотариальных документов» ${ }^{7}$.

По странному стечению обстоятельств российские актовые материалы XVIII в. (в отличие от аналогичных источников предшествующих столетий) до сих пор остаются в значительной степени terra incognita социальной истории. Это тем более удивительно, что в петровское время нотариальное дело претерпело революционные изменения, которые способствовали качественному увеличению числа зарегистрированных (и, следовательно, сохранившихся в государственных архивах) сделок. Как известно, первоначальным импульсом для этих изменений послужили фискальные интересы правительства. Квази-нотариальный институт площадных подьячих, который при определенных условиях мог бы переродиться в подобие французского нотариата ${ }^{8}$, в начале XVIII в. был уничтожен. На его месте была создана система государственных органов («крепостные конторы»), действовавших как в центре, так и в провинции, в которых оказались сосредоточены функции оформления частных актов и, одновременно, сбора в казну соответствующих пошлин. Регистрации в «крепостных» учреждениях и занесению в специальные записные («крепостные») книги подлежали все без исключения акты, под угрозой штрафа и недействительности совершенных сделок. При этом процедура совершения «крепостей» была строго регламентирована 9 .

Еще в 1959 г. Г.Д. Капустина, впервые взявшая на себя труд описать удивительное богатство актовых материалов Московской крепостной конторы, с удивлением отмечала: «акты XVIII в. до сих пор не изучены». В своей замечательной источниковедческой статье Г.Д. Капустина показала исключительный потенциал записных книг Московской крепостной конторы. Это не только огромное количество купчих и закладных на земельные владения (в одной лишь Москве петровского времени регистрировалось около 1000 земельных сделок в год), завещания и брачные контракты (о которых речь пойдет ниже), но также договоры купли-продажи и найма на избы, дворы и лавки в Москве, купчие, меновые и отпускные на крепостных 
людей, различные поручные записи, в том числе акты о приеме новых членов в московский посад, подрядные записи на поставку различных товаров и контракты на строительные работы, договоры о выдаче займов, акты личного найма в работники и подмастерья (т.н. «жилые записи») и многое другое. По замечанию Г.Д. Капустиной, в записных книгах нередко встречаются акты, которые «писцы крепостной конторы не могли отнести ни к одному из известных актов и присваивали им произвольные названия» ${ }^{10}$.

Этот бесценный для «новой социальной истории» России XVIII в. эмпирический материал заключается в 1935 объемистых записных книгах в старых кожаных переплетах, в которые на протяжении 1701-1782 г. писцы Московской крепостной конторы изо дня в день копировали различные акты. Однако собрание московских актов - лишь вершина айсберга. Архивы крепостных учреждений, действовавших в XVIII в. по всей России, также неплохо сохранились. В середине XX в. они были объединены в одну архивную коллекцию под названием «Крепостные книги местных учреждений» (РГАДА, ф. 615). В этом фонде содержится 13609 крепостных книг (в основном относящихся к XVIII в.) по 226 городам и 92 более мелким населенным пунктам ${ }^{11}$. Кроме этого, в распоряжении исследователей имеется коллекция из 730 записных книг Петербургской крепостной конторы ${ }^{12}$. Количество актов, зафиксированных в сохранившихся крепостных книгах XVIII в., несомненно, исчисляется миллионами единиц ${ }^{13}$.

Возможно, именно фундаментальное исследование Г.Д. Капустиной стимулировало кратковременную вспышку исследовательского интереса к актовым материалам XVIII в. ${ }^{14}$ Интересно, что заметный рост внимания советских ученых к частным договорам XVIII в. наблюдался в 60-70-е гг. $\mathrm{XX}$ в., т.е. именно тогда, когда французская историческая наука переживала «нотариальную эру». Однако, эта кратковременная вспышка интереса советских ученых к актам XVIII в. не послужила началом систематического изучения российских крепостных книг имперского периода (к которому призывала в своей статье Г.Д. Капустина). Постепенное возрождение исследовательского интереса к актовым материалам XVIII в. наблюдается лишь с начала нынешнего столетия, что, очевидно, связано с актуализацией вопросов «новой социальной истории» и «истории повседневности» в современной историографической ситуации ${ }^{15}$.

В данном обзоре будут рассмотрены три опубликованные в 2015-2018 гг. работы, в центре которых находятся частные акты. Академическая публикация семейно-правовых актов дворян Москвыпетровского времени, подготовленная профессором МГУ Н.В. Козловой и ее ученицей А.Ю. Прокофьевой, позволяет оценить значение завещаний, брачных договоров и раздельных записей, содержащихся в записных книгах крепостных учреждений XVIII в. Монографический очерк профессора НИУ ВШЭ А.Б. Каменского, опубликованный в его последней книге, демонстрирует исключительный потенциал заемных писем и векселей для изучения проблемы межгруппового взаимодействия в российском провинциальном городе XVIII в. Третья 
публикация представляет собой аналитическое описание документов коллекции «Грамоты Коллегии экономии» - крупнейшего собрания актов, ранее принадлежавших монастырям и архиерейским домам, конфискованных в ходе секуляризационной реформы Екатерины II. В 2016 и 2018 гг. сотрудник Российского государственного архива древних актов А.В. Антонов опубликовал первые два тома, а в настоящее время ведется работа над подготовкой к изданию третьего и последнего тома этого грандиозного описания. Несмотря на то, что традиционно собрание грамот Коллегии экономии привлекает внимание исследователей средневековой истории, в нем содержится немало чрезвычайно интересных актов XVIII в., на которые, кажется, никто ранее не обращал никакого внимания. ${ }^{16}$ Выбранные для обзора публикации представляют, с одной стороны, разные сегменты богатой и малоизведанной совокупности актового материала XVIII в., а с другой стороны демонстрируют различные пути их научного освоения.

\section{«Духовные» и «сговорные» записи в книгах крепостных контор}

Документальный сборник «Дворяне Москвы» является продолжением публикации Н.В. Козловой 2002 г., в которую были включены все официально зарегистрированные в Москве XVIII в. семейно-правовые акты купцов и разночинцев ${ }^{17}$. К «разночинцам» автор публикации отнесла представителей различных непривилегированных социальных групп, таких как канцелярские служащие, священно- и церковнослужители, отставные солдаты, оброчные крестьяне и др. В этом сборнике было опубликовано 383 семейно-правовых акта (197 завещаний, 104 брачных контракта и 82 раздельных и рядных записи), заключенных в 1701-1799 гг. в Московской крепостной конторе. Завещания и брачные контракты регистрировались в книгах, именуемых «рядными», где также записывались отпускные, купчие и « поступные» на дворовых и крестьян, заемные, раздельные и прочие акты. Для обнаружения нужных документов Н.В. Козлова осуществила постраничный просмотр многих десятков дел в сотни, а то и тысячи листов каждое. Работая над выявлением завещаний и брачных контрактов купцов и «разночинцев», Н.В. Козлова обратила внимание на то, что «основная масса семейно-правовых документов, сохранившихся в фонде Юстиц-коллегии, относится к проживавшему в Москве дворянству, по другим же разрядам московского населения их значительно меньше (в большинстве книг от 1 до 9 записей) или нет вовсе)» ${ }^{18}$. Это побудило исследовательницу осуществить новую публикацию заключенных в Москве дворянских семейно-правовых актов, ограничившись при этом петровским временем. На этот раз было опубликовано 888 договора (326 завещаний, 499 сговорных и 63 рядных), заключенных в Москве в 1699-1725 гг. «дворянами разного социального статуса, чина и имущественного положения» (С. 9). Обе публикации предваряются обстоятельными аналитическими обзорами, а также содержат подробные 
комментарии, некоторые из которых представляют собой самостоятельные и довольно трудоемкие мини-исследования.

Саму идею разбивки актового материала по социальным категориям («купцы», «разночинцы», «дворяне») нельзя признать удачной, особенно ввиду того, что в настоящее время наиболее актуальной задачей социальной истории является изучение межгруппового взаимодействия. Впрочем, если рассматривать два сборника в комплексе, мы получим 1271 договоров, имеющих отношение к урегулированию семейных отношений представителей различных социальных групп, проживавших в Москве XVIII в. Из них 943 сделки первой четверти XVIII в. представляют собой полный комплекс официально зарегистрированных в Москве петровского времени семейно-правовых актов.

Примечательно, что более чем в 90 процентах семейно-правовых актов первой четверти XVIII в., занесенных в книги Московской крепостной конторы, в качестве контрагентов выступали именно дворяне. При этом дворянство являлось одной из самых малочисленных групп московского населения. Так, по подсчетам Е.И. Заозерской, из 44885 человек, принесших присягу Екатерине I в 1725 г., к дворянам («высшие гражданские, военные чины и «штяхетство») относились лишь 3111 человек (т.е. 6,94\%) Это наводит на мысль, что в Москве петровского времени официально регистрировалось лишь незначительное количество завещаний и брачных договоров.

Тем не менее, значение сохранившихся в крепостных книгах семейно-правовых актов сложно переоценить. Я лишь приведу несколько примеров, непосредственно относящихся к обозначенным в самом начале обзора проблемам социальной идентичности и взаимодействия представителей различных социальных групп в повседневной жизни. Первого сентября 1731 г. 71-летний купец Алексей Остафьевич Филатьев, старейший представитель одной из виднейших купеческих фамилий XVII-XVIII в., находясь в своем доме в Китай-городе на Ильинской улице, продиктовал «изустную духовную», которая несколько месяцев спустя, после смерти завещателя, была зарегистрирована в Московской крепостной конторе (важно подчеркнуть, что завещания, также как и сговорные, нередко составлялись именно в домашних условиях, что, возможно, в некоторых случаях избавляло их содержание от влияния канцелярских служащих $)^{20}$. При этой торжественной сцене присутствовали, кроме самого завещателя, семь человек (каждый из них подтвердил свое участие подписью на документе): родной внук А.О. Филатьева Петр Дмитриевич, который и являлся его главным наследником; двое священников (духовный отец умирающего и настоятель ближайшей церкви Вознесения Господня, что в Ипатьевском переулке), а также «ближние свойственники» и «приятели» завещателя: «монетных дворов казначей» Иван Дмитриев сын Алмазов, «гостиный сын» Андрей Остафьев сын Филатьев (младший брат завещателя), «манетных дворов казначей» Иван Иванов сын Мокеев (дед главного наследника со 
стороны матери) и «отставной провинцыал фискал» Савва Яковлев сын Турченинов. Порядок расположения подписей под духовной не случаен: он, по наблюдениям Н.В. Козловой, зависел «от степени родственной, служебной или дружеской близости к лицам, упоминаемым в документах» (с. 49). Также не случайны и те формулировки, которые использовали свидетели для обозначения своего социального статуса. Так, дед наследника Петра по матери Иван Иванович Мокеев, принадлежавший к московской купеческой семье 1-й гильдии, ${ }^{21}$ пожелавший указать в подписи, что он был «монетных дворов минцмейстер», действительно считался большим экспертом в области монетного дела и входил в состав Комиссии о монетном деле 1730-1731 гг,, где работал вместе с В.Н. Татищевым, П.И. Мусиным-Пушкиным, президентом Берг-коллегии А.К. Зыбиным и виднейшими представителями московского купечества 22 .

В своем завещании купец определял наследником всего своего состояния четырнадцатилетнего внука Петра. При этом он заповедал присутствовавшим при составлении завещания «приятелям» и «милостивым свойственникам» не оставлять своего несовершеннолетнего внука, а Петру приказал «быть у них во всяком послушании, и без ведома их ничего не чинить». Находясь при смерти, А.О. Филатьев переживал за будущее своего достояния. Поэтому, при составлении завещания в пользу юного внука, старик не жалел слов наставлений, увещеваний и даже заклинаний, которые были включены в текст «духовной». Между прочим, старик наставлял внука: «А ежели ты пожелаешь законной брак возъиметь, и тебе б невесту отъискивать ис купечества, а из шляхетства не соизволяю тебе и запрещаю». И далее, как будто поясняя свой запрет, старый купец продолжал: «запрещаю с мотами, и безделниками, и с зернщиками, и с тунеятцами отнюдь не знатся, о чем тебе под великою клятвою запрещаю. И от блуда иметь чистоту и воздержание, и от прелесниц бегать, и иметь их от себя отриновенных, и боятся того, яко лютого змия, чтоб тебе от Бога, в Троице славимаго, не прогневать и в напасть не притти, от чего всегда блудники пропадают безвремянными казнми от Бога и наказаны бывают... А охот тебе по твоем летам никаких непотребных не держать. И хотя при своей жизни по твоему желанию в том и не воспрещал, не хотя тебя во юности раздражить, а после тебе сие творить весма с клятвою запрещаю...» ${ }^{23}$.

Очевидно, эти наставления, высказанные старым купцом на смертном одре, в собственном доме, в окружении домочадцев, священников, ближайших родственников и «свойственников», представляют собой яркий образчик выражения социальной идентичности. Действительно, беглый просмотр опубликованных в сборниках брачных контрактов показывает, что московские жители XVIII в., подобно французам Старого порядка, часто «женились на ровне» ${ }^{24}$. Так, 11 августа 1702 г. в Московской крепостной конторе было зарегистрирована «сговорная» купца Садовой слободы Кондратия Романова сына Хвасливого, который «сговорил» «племянницу свою девицу» Марью Савельеву замуж за купца Конюшенной Овчинной 
слободы Григория Иванова сына Шумилова с приданным различных вещей и денег на 130 рублей. В качестве свидетелей выступили купцы Конюшенной Овчинной слободы Григорий Михайлов сын Карманов и Садовой слободы Стефан Андреев сын Дьяконов ${ }^{25}$. А несколько дней спустя в стенах той же Московской крепостной конторы был зарегистрирован брачный контракт, по которому вдова стольника князя Федора Никитина Примакова-Ростовского выдала свою дочь, «девицу княжну Елену», замуж за стольника князя Василия Михайловича Долгорукова с приданым 2000 рублей денег и вотчинами. В качестве свидетелей выступили князья Авраам Никитич Примаков-Ростовский, Юрий Юрьевич Одоевский, Владимир Михайлович Долгорукий, Федор Иванович Щепин-Ростовский, а также Федор Григорьев сын Неелов и Иван Михайлов сын Кашаев (С. 426).

Но все же в документальных сборниках обнаруживается немало случаев необычных браков, свидетельствующих о динамичности русского общества и проницаемости перегородок, отделявших различные социальные группы друг от друга. Так, 22 апреля 1718 г. купец гостиной сотни Федор Герасимов сын Нестеров «сговорил» свою племянницу, вдову Феклу Иванову, которая ранее была женой дворянина, покойного поручика Степана Михайлова сына Шушерина, замуж за «лейб-гвардии Преображенского полку адьютанта» Александра Титова сына Раевского, дав за нее приданного различных вещей на 2500 рублей и наличных денег 500 рублей. В качестве свидетелей на этом сговоре выступили 22 человека, и при этом ни одного купца, но все дворяне, в основном - солдаты и офицеры Преображенского полка. Любопытно, что несколько человек подписалось под документом дважды (возможно, вследствие суматохи или алкогольного опьянения $)^{26}$. Четырнадцатого января 1703 г. «человек» (возможно, холоп) князя Дмитрия Михайловича Голицына Никита Семенов сын Неустроев «сговорил» свою дочь Стефаниду замуж за подьячего Монастырского приказа Степана Шипилова. При этом в качестве приданого он отписал различных вещей и денег на 600 рублей, а также «малого и девку» (т.е. двух крепостных людей) в придачу. Как отметила Н.В. Козлова, это приданое, которое собрал для своей дочери «человек» князя Голицына, сопоставимо с приданым многих дворян (С. 56). Свидетелями этого сговора выступили люди значительно более высокого социального статуса: стольник Евтифий Суворов, «задворный конюх» (допетровский придворный чин) Василий Белкин, стряпчий тверского архиерея Иван Усачев, стряпчие Калязина монастыря Тимофей Шадеев и Филипп Чередеев, а также подьячий Монастырского приказа Александр Крутов (С. 426).

Ценнейшей информацией о межгрупповом взаимодействии в повседневной жизни изобилуют не только сговорные, но также и завещания. Например, 20 марта 1720 г. капитан Петр Ильин сын Сверчков в своем завещании распорядился всем его дворовым людям «дать отпускные, куда хотят», а тем людям, которые находились при нем, «отказал» одному «лошадь мерина серово, епанчю васильковую, шпагу малую, котел маленькой, кафтан темно зеленый», другому - «лошадь мерин голубой, третьему - «лошадь, малой 
серой мерин, да старой кафтан компанейной, зеленой подбой» (С. 282). Точно также боярин Федор Петрович Шереметев (родной брат прославленного генерала-фельдмаршала), составивший завещание 24 мая 1723 г., перед отъездом из Москвы в Санкт-Петербург, опасаясь «по отъезде своем в Санкт Питербурх в скорби моей смертного часа», велел своему наследнику, племяннику В.В. Шереметеву, отпустить всех служивших в его московском доме дворовых людей, особенно отметив заслуги Якова Степанова сына Громова, заведовавшего хозяйственной частью, который «по домовным моим книгам в приходе и росходе щитан, и начету на нем никакова не явилось». C благодарностью упомянул Шереметев и своего конюха Евдокима Васильева, которого он когда-то взял в московский дом вместе с женой и детьми из крестьян своей рязанской вотчины (С. 346). Как видим, эти и многие другие «духовные» рисуют далеко не антагонистические отношения между дворянами и их крепостными людьми.

Важно также отметить, что почти во всех завещаниях имеются распоряжения финансово-хозяйственного порядка: о взыскании или выплате долгов, о произведении расчетов с деловыми партнерами и т.п. Этот элемент «духовных» предоставляет уникальные сведения о повседневном межгрупповом взаимодействии на почве хозяйственной деятельности. И здесь семейно-правовые акты пересекаются с другой разновидностью актов - долговыми письмами и векселями, которые оказались в центре внимания А.Б. Каменского.

\section{Книги протеста векселей XVIII в. и их значение для изучения социальной истории имперской России}

Стремясь к контролю над всеми сделками, правительство Петра столкнулось со своего рода Eigensinn, проявлением «своевольного упрямства» (по выражению Альфа Людке) населения. Многие российские подданные по-прежнему составляли акты «не у крепостных дел», а «своеручно». Правительство хотя и боролось с этими нарушениями, но все же было вынуждено идти на уступки, допуская различные исключения из установленной процедуры совершения актов в крепостных учреждениях. Так, в 1711 г. было разрешено заключать некоторые сделки на Московском гостином дворе, для чего туда были назначены два надсмотрщика и четыре писца. В 1716 г. казенным подрядчикам было позволено заключать договоры не в крепостных конторах, а прямо в канцеляриях без уплаты пошлин, «понеже по взятье с того крепостных пошлин прибытку казне Его Императорского Величества нет, потому, на оные расходы подрядчики прибавляют в договорах излишнюю цену, да и подрядчикам от письма тех крепостей чинится волокита немалая». В 1721 г. было разрешено совершать сделки между купцами не в крепостной конторе, а в Главном магистрате, где для этого учреждалась специальная должность «маклера», который должен был вести для записи сделок «маклерский 
журнал». После смерти Петра I, в 1727 г. было разрешено «писать приданые росписи и духовные домашним порядком». Наконец, нужды торговли, в особенности опасность перевоза «по такой обширной Империи» наличных денег, стали причиной, по которой правительство в 1729 г. пошло на разрешение свободного составления и обращения векселей ${ }^{27}$.

Среди прочих разновидностей денежных актов (по классификации С.M. Каштанова $\left.{ }^{28}\right)$ вексель отличается тем, что для его оформления не требовалась ни гербовая бумага, ни участие свидетелей или поручителей, ни даже регистрация в государственном учреждении. По словам А.Б. Каменского, «это был в полном смысле частноправовой и по-своему уникальный для XVIII в. акт» (С. 32). Правда, сами векселя XVIII в. до нас не дошли (т.к. они хранились у частных лиц и уничтожались при погашении долга). Но зато в распоряжении исследователя имеются копии неоплаченных вовремя и официально опротестованных векселей, сохранившиеся в составе специальных годовых книг протеста векселей, которые велись в органах городского управления ${ }^{29}$. Согласно формуляру, утвержденному уставом 1729 г., вексель обязательно включал в себя, помимо информации о сделке (месте и дате ее заключения, размере и сроке уплаты долга), информацию о социальном статусе контрагентов. Как отмечает А.Б. Каменский, «поскольку векселя составлялись не чиновниками государственных учреждений, а самими участниками сделки, то правильнее говорить об отражении в этих документах их самоидентификации» (С. 36-37). Это обстоятельство, также как массовость и хорошая сохранность книг протеста векселей, определяет исключительную привлекательность этой разновидности актового материала для исследований в русле «новой социальной истории».

Монографический очерк А.Б. Каменского «Кредиторы и должники у русской провинции XVIII в.» является продолжением исследования о повседневности жителей Бежецка XVIII в., в котором автор не коснулся финансово-хозяйственной деятельности горожан ${ }^{30}$. Обнаруженные автором материалы (главным образом, явочные челобитные и судебные дела) показали необходимость специального исследования на эту тему: «в использованных документах фигурировали подчас довольно значительные денежные суммы, резко контрастирующие не только со сложившимися в историографии представлениями о благосостоянии городского населения этого времени, но и стараниями самих бежечан представить себя в глазах власти убогими и малоимущими». Это противоречие заставило А.Б. Каменского вновь обратиться к материалам Бежецкой земской избы, ратуши и городового магистрата с целью «реконструкции экономических аспектов повседневной жизни горожан XVIII в.» (C. 14-15). В основу исследования легли 25 годовыХ книг протеста векселей, которые велись в Бежецкой ратуше в 1740-1775 гг. По предположению А.Б. Каменского, в 1730-х гг. практика составления векселей еще не получила распространения среди бежецкого купечества. В первые четыре десятилетия XVIII в. денежные обязательства «оформлялись иначе - в виде кабальных записей и заемных писем», которые регистрировались в 
крепостных учреждениях, а в случае неуплаты долга становились объектом разбирательства в том же самом Бежецком магистрате. Материалы этих судебных тяжб позволили дополнить информацию книг протеста векселей. В итоге А.Б. Каменскому удалось составить базу данных о долговых обязательствах, в которой учтены 2448 случая за 1698-1775 гг. (С. 29)

ПервоначальнойцельюработыА.Б.Каменскогобылополучение«достаточно репрезентативного корпуса информации о финансово-хозяйственной деятельности горожан». Однако источник определил несколько иную траекторию исследования. Оказалось, что «вексель - это гораздо более информативный источник, чем можно думать, исходя лишь из цели его создания. Содержащаяся в нем многоаспектная информация далеко выходит за пределы только историко-экономической проблематики». Кроме этого, среди участников сделок обнаруживаются не только бежецкие купцы, но и в значительной степени представители других социальных групп (36,7 \% участников вексельных сделок - с. 49). Это обстоятельство навело исследователя на мысль, что анализ заемных писем и векселей «позволяет проникнуть в одно из тех пространств, где происходило взаимодействие различных социальных групп русского общества XVIII в.» (С. 29-30). Так исследование, изначально задуманное как историко-экономическое, привело А.Б. Каменского к вопросам о том, «как было устроено русское общество этого времени, как и почему это устройство менялось на протяжении столетия, в том числе под влиянием преобразований начала века» (С. 14-15). Информация, содержащаяся в книгах протеста векселей, дополняется в очерке многими другими источниками: судебными делами, ревизскими сказками, книгами записи доверенностей и др.

Подавляющее большинство заемных писем и векселей, оказавшихся в базе данных А.Б. Каменского, были выписаны в самом Бежецке (более 80 \% случаев) на сумму, не превышающую 100 рублей (впрочем, было немало и интересных исключений: минимальный долг - 1 рубль, а максимальный 2300 рублей - с. 42-44). В основном, участниками вексельных сделок были бежецкие купцы. Из них выделяется несколько лиц, которые занимались этой деятельностью гораздо более активно, чем остальные. Один из самых состоятельных и предприимчивых бежецких купцов Михаил Лукич Ревякин, видимо, выполнял функцию местного банкира: в 1749-1775 гг. он опротестовал 120 векселей, выписанных на его имя со стороны представителей самых различных социальных групп (С. 91-94). Интересно было бы пойти дальше и поразмышлять, как влияла подобная деятельность на реальное положение заимодавца в городе ${ }^{31}$. В этом смысле любопытна фигура Андрея Андреевича Загадашникова, выходца из монастырских крестьян, который, обладая предпринимательской жилкой, записался в бежецкое купечество, затем перевел в город свою большую крестьянскую семью (четырех братьев с их семьями, которые в официальных документах стали именоваться бежецкими «жителями»), где развернул активную хозяйственную деятельность (при этом, когда речь заходила об уплате подушной подати, Загадашников 
вспоминал о своем крестьянском происхождении) $)^{32}$. Будучи одним из самых активных заимодавцев Бежецка, он при этом пользовался большим доверием горожан: так, в 1759 г. Загадашников по поручению прихожан бежецкой церкви Николая Чудотворца исполнил деликатную миссию ходатайствовать перед архиепископом за их духовного отца, священника Иоанна Романова, которого за какие-то проступки отлучили от службы (С. 87-90).

Как уже было упомянуто, в более тридцати процентов сделок в качестве контрагентов выступали представители иных социальных групп (не бежецкие купцы). В 332 случаях (13,5 \%) участниками сделок оказывались крестьяне, которые брали у горожан незначительные суммы (средний размер сделки - чуть более 15 рублей - с. 55). Как показал А.Б. Каменский, эти деньги, скорее всего, использовались крестьянами для уплаты подушной подати. Так, в 1759 г. 29 дворцовых крестьян разных деревень взяли в долг у бежецкого купца А.И. Буркова 20 руб. сроком на восемь месяцев. Интересно, что на каждого из крестьян «приходится около 69 коп. долга, то есть сумма, близкая к размеру подушной подати». Также любопытно, что «Бурков был самым активным из всех бежечан участником сделок с крестьянами», т.е специализировался на обеспечении крестьян мелкими ссудами (С. 85). Таким образом, векселя позволяют рассмотреть механизм получения крестьянами наличных денег для выплаты подушных денег посредством взаимодействия с отдельными городскими купцами.

Точно также в роли заемщиков выступало большинство дворян, но правда средний размер их займов был в десять раз больше крестьянских (С. 56). Например, в 1770 г. подпоручик Прокофий Иванович Фомин одолжил у вышеупомянутого купца М.Л. Ревякина 550 рублей «на покупку в бежецком магистрате сельца Печкова со крестьяны» (С. 84). Впрочем, дворяне выступали и в роли заимодавцев гораздо чаще крестьян (дворяне сами одолжили деньги в 89 случаях из 200). В вексельных сделках принимали довольно активное участие и канцелярские служащие (канцеляристы, подканцеляристы, копиисты и пр. - 169 кейсов, 7 процентов от общего числа операций). Причем они также играли свою специфическую роль, нередко выступая в качестве лиц, на которых переводили векселя для взыскания денег с должников. А.Б. Каменский объясняет это тем, что «у канцелярских служащих, в особенности работавших в воеводской канцелярии, было больше возможностей взыскивать долги с дворян, чем у простых купцов» (С. 97-98).

Наблюдение над использованием терминов при обозначении социального статуса позволяет А.Б. Каменскому сделать интересное наблюдение относительно того, «каким русское общество виделось «снизу», то есть глазами тех, кто его собственно и составлял, в то время как сами сделки были одной из форм взаимодействия между разными социальными группами» (С. 72). Примечательно, что в большинстве случаев дворяне при оформлении сделок предпочитали обозначать свой чин по Табели о рангов (и это несмотря на то, что вексель не следовало регистрировать официально) (С. 57-58). Во многих случаях «с точки зрения самоидентификации чин или должность для 
русского человека XVIII в. были гораздо важнее сословной принадлежности» (С. 65). Если принадлежность к сословию для отдельного индивидуума была расплывчатой и «связанной почти исключительно с фискальными обязательствами», то исполнение определенной «должности пусть даже выборной и временной, выделяло индивида из массы, наделяло конкретными обязанностями и властными полномочиями и четко определяло положение человека в обществе. Обладатель должности, таким образом, становился обладателем и определенного социального капитала, и именно поэтому должность для него являлась большей ценностью, чем принадлежность к сословию» (С. 72). Это наблюдение соотносится с выводом о восприятии горожанами выборных служб, сделанным в книге 2006 г. на основании судебных материалов: «возможность избираться на городовые службы была свидетельством полноценного членства в городовом обществе, т.е. определенного социального статуса» ${ }^{33}$. В других случаях россияне XVIII в. различали друг друга по роду занятий. Эти наблюдения навели А.Б. Каменского на предположение, что «наряду с социальной структурой, закрепленной в законодательстве и используемой государством в управленческих, прежде всего фискальных целях, одновременно с ней существовала по меньшей мере еще одна, гораздо более подвижная и основанная на роде занятий отдельных групп населения. Обе эти виртуальные структуры пересекались, накладывались одна на другую и выходили на первый план в зависимости от конкретных ситуаций» (С. 79).

Таким образом, векселя предоставляют исследователю уникальную информацию для размышления над вопросами, которые ставит «новая социальная история». Вместе с этим, книги записи векселей заслуживают осторожного отношения. Действительно, в эти книги записывались только не выплаченные в срок и опротестованные векселя. Следовательно, книги протеста векселей рисуют несколько искаженную картину. Например, из всех церковнослужителей наиболее активными участниками вексельных сделок были дьячки местной церкви Василий и Евстафий Тимофеевы. При этом из текста одного из векселей на 14 рублей, выданного в 1762 г. дьячком Евстафием Тимофеевым бежецкому купцу И.П. Первухину, сообщается, что за выданные деньги церковнослужитель должен был «поставить коровья масла десять пуд ценою по рублю по сороку копеек» (С. 68). Из этого А.Б. Каменский делает заключение «о характере хозяйственной деятельности служителя церкви». Но, раз этот вексель оказался опротестован, не следует ли из этого, что дьячок, напротив, не поставил товар своему заимодавцу? Очевидно, если бы он имел налаженный бизнес по производству масла, его имя вообще не фигурировало бы в книге протеста векселей.

Итак, книги протеста векселей, также как и крепостные книги, накладывают на исследователя серьезные ограничения: в первых фиксировались только не выплаченные в срок и опротестованные векселя, а во вторых находили отражение лишь официально зарегистрированные сделки. В рамках же обозначенной проблемы повседневного взаимодействия представителей 
различных социальных групп очень важно представить, какой же объем разнообразных сделок (в том числе и официально не регистрировавшихся) могло совершать одно лицо или семья, а также обрисовать весь круг его контрагентов. Но, к сожалению, подлинные акты в частных архивах сохранились крайне фрагментарно. ${ }^{34}$ Зато в распоряжении исследователей имеются комплексы актового материала, сохранившиеся в монастырских архивах.

\section{Подлинные частные акты XVIII в. в монастырских архивах}

Во время секуляризации монастырских и архиерейских земельных владений в 1763-1764 гг. из монастырей всей России было свезено в Москву, в специально созданную для управления церковными вотчинами Коллегию экономии, огромное количество документов (в основном, актов). По оценке В.Б. Кобрина, в собрание «грамот» Коллегии экономии, в подлинниках или списках, попало около двух третей (или, во всяким случае, не менее половины) всех монастырских актов ${ }^{35}$. После упразднения Коллегии экономии в 1786 г. $^{36}$ эти материалы (около 16 тысяч документов, связанных с монастырской земельной собственностью - актов, выписок из писцовых книг и ревизских сказок и пр.) были переданы на хранение в Московский государственный архив старых дел (в 1852 г. он вошел в состав Московского архива Министерства юстиции), где они некоторое время хранились, по выражению П.М. Строева, в виде «безобразных груд разного старья» ${ }^{37}$. В 1848-1859 гг. была осуществлена обработка этого собрания. В основу организации коллекции был положен территориальный принцип: все «грамоты» были систематизированы не по монастырям-владельцам (т.е. не по фондообразователям), а по уездам (в соответствии с современным описанию административным делением), в которых располагались упомянутые в актах земельные владения. Материалы в пределах одного уезда были систематизированы по хронологии, а затем пронумерованы и описаны. Составленные в результате этой работы описи (20 рукописных томов), а также географический и хронологический указатель до последнего времени являлись главным инструментом для исследователей ${ }^{38}$.

Необходимость создания и публикации новой, более точной, удобной и доступной для ученых описи грамот Коллегии экономии остро осознавалась уже во второй XIX столетии. В 1879-1884 гг. сотрудником Московского архива Министерства юстиции Д.М. Мейчиком было подготовлено и опубликовано систематическое научное обозрение древнейших грамот этой коллекции (до начала XVI в.) ${ }^{39}$. В 1895 г. аналитическое описание собрания грамот Коллегии экономии продолжил другой архивный работник С.А. Шумаков, который, к сожалению, вскоре был отстранен от этой работы из-за конфликта с директором архива Д.Я. Самоквасовым ${ }^{40}$. Однако Шумаков, рассматривая описание грамот Коллегии экономии как важнейшее дело своей жизни, 
решил продолжить эту работу самостоятельно, пойдя по пути публикации поуездных систематическо-хронологических обзоров. К сожалению, реализовать задуманный план целиком С.А. Шумакову не удалось: он успел подготовить лишь четыре выпуска с обзорами документов по нескольким уездам $^{41}$. Параллельно, в Академии наук с 1900 г. под руководством А.С. Лаппо-Данилевского велась работа по публикации грамот Коллегии экономии (при участии того же С.А. Шумакова). Однако и эта работа так и не была завершена: из запланированных 20 томов вышли в свет только два ${ }^{42}$.

Между тем, исследователи с нетерпением ждали публикации аналитического обзора документов коллекции, относящихся к XVI-XVIII вв. Так, М.А. Дьяконов в 1900 г. с сожалением писал: «администрация архива, в котором хранятся эти грамоты (Коллегии экономии. - E.A.) до сих пор почти ничего не сделала для того, чтобы издать хотя бы описи, не говоря уже об актах. Прежде, когда описания документов, хранящихся в этом архиве, выходили в свет не столь редко, как в последние восемь лет, издано было хорошее описание этого собрания, но лишь до XVI века. Следовало бы ожидать продолжения этой описи и далее, но его нет и по всем видимостям долго не будет» ${ }^{43}$.

Таким образом, до последнего времени исследователи при работе с этой богатейшей коллекцией актового материала были вынуждены пользоваться инструментарием, созданным в 40-50-е гг. XIX в., на заре развития российской археографии, и не отвечавшим потребностям науки уже во второй половине XIX в. В этом контексте становится ясной значимость описания, предпринятого А.В. Антоновым. По справедливому замечанию самого автора, «за прошедшие полтора века со времени составления архивной описи ГКЭ назрела необходимость их нового описания с учетом требований современной археографии. Прежде всего, это касается более точного и подробного составления заголовков документов, определения их разновидности, датировки, установления фондообразователя и отражения сведений о публикации или упоминаний в различных обзорах и перечнях» (T. 1, С. 3). На настоящий момент изданы два массивных тома описания общим объемом более 2500 страниц, в которых опубликованы описания 10793 документов собрания грамот Коллегии экономии (сегодня этот фонд насчитывает 15194 единицы хранения) $)^{44}$. Соответственно, на данный момент исследователям уже доступно современное описание $2 / 3$ документов собрания. Надо полагать, последний третий том описания будет опубликован в ближайшие два-три года.

Описательные статьи, из которых состоит данный архивный справочник, включают в себя следующие элементы: 1) инвентарный и внутренний номер; 2) дата документа; 3) заголовок документа (его название, контрагенты, объект сделки);4)идентификацияфондообразователя(названиемонастыря-владельца), аутентичность и размеры акта, наличие печатей и подписей должностных лиц; 5) сведения о публикациях документа, а также его упоминания в различных обзорах и перечнях. Как мне представляется, описательные статьи выполнены 
на самом высоком научном уровне. Они существенно превосходят рукописную опись 40-50-х гг. XIX в. Чтобы это продемонстрировать, достаточно привести лишь один случайно выбранный пример.

\begin{tabular}{|l|l|}
\hline \multicolumn{1}{|c|}{ Заголовок старой описи: } & \multicolumn{1}{|c|}{ Заголовок описания А.В. Антонова: } \\
\hline № $2212 / 435.1730$ сентября & № 2212/435. 1730 г. сентября 25. - Мировая \\
25 дня. Запись, данная & запись Федосьи Артемьевой дочери, вдовы \\
от Федосьи Ивановой & Ивана Михайлова сына Сурмина, и крестьян ее \\
жены Сурминой игуменье & вотчины деревни Матренино игуменье Успенского \\
Владимирского Успенского & владимирского девичьего монастыря Екатерине \\
девичья монастыря & с обязательством не вступаться в монастырские \\
Екатерине с сестрами на & пустоши Лысково, Демидово и др. в Ильмехотском \\
владение землями и сенными & стану Владимирского уезда с регистрационнй \\
покосами в пустошах & записью во Владимирской конторе Крепостных дел. \\
Губиной и Аксиньиной. & Подлинная рукопись в 2 (205 Х 325) на 2-хлл. \\
Запись эта писана & Успенский Княгинин владимирский девичий \\
современною скорописью на & монастьрь. \\
2-х листах гербовой бумаги & Упоминания: Шумаков. Обзор. М., 2002. Вып. 5. С. \\
обыкновенного формата45. & 117, 118. № 228 (Т. 1. С. 404-405). \\
\hline
\end{tabular}

Как мы видим, в новом описании происходит не только существенное уточнение заголовка (в данном случае, определение разновидности акта), но также исправление имен контрагентов и географических названий. Особое значение имеет переописание копийных сборников актов, содержание которых старая опись передавала очень неточно, на что еще в 1900 г. обратил внимание С.А. Шумаков: «особенно же неудовлетворительны старые архивные описи таких ценных вещей, как сборники копий XVII в. с актов XIV-XVII вв., из которых подлинники многих не дошли до нас... архивные описи не только не помогают разобраться во всем этом хаосе, но еще более запутывают его» ${ }^{46}$. Например, в старой описи документ под № 6059/25 обозначен как «список с правой грамоты архимандриту Нижегородского благовещенского монастыря Дионисию по спорному делу о земле в пустынке Миромирской, что на Столбищах» $1626 \Gamma^{47}$ Но в действительности этот документ представляет собой копийную книгу Патриаршего казенного приказа середины XVII в., в которой были собраны списки с различных актов, подтверждающих права Благовещенского патриаршего нижегородского монастыря на владение селом Столбище Подгородного стана Курмышского уезда. Описательная статья этой копийной книги, которая включает в себя более трех десятков документов (начиная с правой грамоты, давшей название заголовку в старой описи), занимает в описании А.В. Антонова три страницы текста убористым шрифтом (T. 1. C. 194-196).

Заголовки описания А.В. Антонова выстроены в строгом соответствии с современными шифрами, т.е. в алфавитном порядке по названиям уездов, в которых располагались земельные владения, а внутри уезда - по хронологии. Соответственно, первый том начинается с описания документов по Алатырскому уезду (№ 1-206), а заканчиваются Иркутским уездом 
(№ 4892-4967). Во втором томе опубликованы описания документов собрания начиная с Костромы (№ 4968-5631) и заканчивая Радонежем (№ 10793). В третьем томе ожидаются описания документов начиная с Саратовского и заканчивая Ярославским уездом. Расположенный таким образом материал предоставляет исследователю не слишком много возможностей для анализа описательных статей. Этот недостаток компенсируется именным и географическим указателями. Последний позволяет вести поиск не только по географическим объектам, но также по названиям монастырей, епископских кафедр и церквей. Таким образом, географический указатель дает возможность вычленить корпус актов, ранее хранившихся в архиве одного монастыря.

Рассмотрим один конкретный пример. По двум томам мы можем выделить более сотни актов петровского времени, заключенных властями Свято-Троицкого Ипатьевского монастыря в Костроме с различными лицами. Не вдаваясь в детальный анализ этого корпуса, требующего изучения текстов документов, отметим, что, судя по описаниям, многие сделки заключались с целью урегулировать или предупредить различные конфликтные ситуации между монастырскими и помещичьими крестьянами Костромского уезда на почве пользования смежными хозяйственными угодьями. Например, 22 апреля 1686 г. монастырь (в лице своего стряпчего Ивана Саввина Кривоперстова) заключил с помещиком Саввой Козьминым сыном Строевым сразу две сделки. Первый договор представляет собой мировое соглашение, по которому Строев брал на себя обязательства не судиться с монастырскими властями за бесчестье его жены и детей, а также убитого крестьянина (видимо, в данном случае имел место серьезный конфликт, закончившийся столкновениями между крестьянами, каким-то образом затронувшими и семью помещика $)^{48}$. По второй сделке, заключенной в тот же день, монастырь обменялся со Строевым пожнями (Т. 2. С. 79-80). Очевидно, эти две сделки связаны друг с другом. Можно предположить, что обмен пожнями не был равноценным и представлял собой своеобразную плату за отказ от судебного разбирательства против монастырских крестьян. Точно также, 8 июня 1688 г. монастырь завершил многолетнюю тяжбу своих костромских крестьян села Колшева с крестьянами помещика Тимофея Михайлова сына Тельцова, заключив мировую сделку о полюбовном размежевании земель (Т. 2. С. 82-83). Таким же мирным порядком решались и некоторые споры с различными помещиками о беглых крестьянах. Так, в марте 1701 г. монастырские власти заключили договор с братьями Иваном и Павлом Дмитриевыми Сипягиными, по которому монастырь получал крепостную крестьянскую семью вместе со всем имуществом взамен укрывавшихся в поместье Сипягиных беглых монастырских крестьян (Т. 2. С. 120). Этот акт был оформлен и зарегистрирован в Костромской приказной избе подьячим Петром Поликарповым. ${ }^{49}$ Интересно, что этот самый Петр Поликарпов ранее, будучи костромским площадным подьячим, нередко выступал в роли нотариуса Ипатьевского монастыря, оформляя различные его сделки. Например, 14 марта 1688 г. именно Петр Поликарпов оформил на костромской площади 
любопытное соглашение между монастырскими властями и владимирским помещиком Леонтием Саламановым о строительстве и последующем совместном использовании плотины и мельницы на р. Судоге на территории, принадлежащей Саламанову во Владимирского уезде. По условиям договора, все строительные работы должны были выполнить монастырские власти, которые при этом могли пользоваться землей и лесом помещика. Монастырь должен был также поставить все необходимое оборудование и прислать своего мельника. Но в дальнейшем все доходы от использования мельницы Саламанову и монастырю следовало делить пополам ${ }^{50}$. Видимо, в качестве компенсации за выделенную под мельницу территорию помещик получил монастырскую пожню Андреевское в Костромского уезде: соответствующая сделка была оформлена в тот же день тем же костромским площадным подьячим Петром Поликарповым (Т. 1. С. 383).

Особый интерес представляют хранившиеся в монастырских архивах подлинные духовные грамоты. Так, в архиве Ипатьевского монастыря сохранилась собственноручное завещание Ивана Иванова сын Шетнева (Т. 2. С. 35), который в 1690-х гг. завещал монастырю все свое имущество, в том числе вотчины, дом, скот, посуду и «пожитки» ${ }^{51}$. В 1716 г. в Ипатьевский монастырь пришел для пострижения бывший подьячий Поместного приказа Лаврентий Постников, который в челобитной на имя архимандрита Тихона сообщил о том, что именно он в свое время помог монастырю узаконить щедрый вклад Шетнева. Старый подьячий напомнил монастырским властям о том, что он оказал эту услугу «без денежных взятков», а лишь «желая от Господа Бога грешной своей душе спасения», а от монастырских властей «при древности милостивого призрения и благодеяния» ${ }^{52}$. Иными словами, условием этой услуги подьячего Поместного приказа и было его пострижение в Ипатьевском монастыре в старости. Вместе с челобитной подьячего была оформлена и его духовная (Т. 2. С. 122), в которой тот завещал братии все свое имущество ${ }^{53}$.

Эти духовные ипатьевских монахов было бы интересно сравнить с завещаниями, сохранившимися в архивах других монастырей. Однако, к сожалению, справочный аппарат описания А.В. Антонова не позволяет этого сделать, так как он не включает в себя предметно-терминологический указатель ${ }^{54}$. Впрочем, возможно автор планирует его включить в последний том описания, но в предисловии об этом ничего не сообщается.

Само предисловие, которым А.В. Антонов снабдил эту эпохальную публикацию, удивляет своей краткостью. Оно занимает всего полторы странички, половина из которых отведена для малосодержательного перечисления включенных в публикацию уездов (эта информация дублируется в оглавлении). Читатель тщетно будет искать в предисловии обзора предшествующих попыток научного описания и публикации собрания грамот Коллегии экономии (в особенности, характеристики деятельности в этом направлении Д.М. Мейчика, С.А. Шумакова и А.С. Лаппо-Данилевского), обоснования собственных принципов описания, оценки репрезентативности и сохранности различных монастырских комплексов и т.п. 
Впрочем, объем проделанной работы, а вместе с тем ее значимость, несомненно, извиняют указанные недостатки. Читателю остается лишь надеятьсянато, чтоаналитическиематериалыипредметно-терминологический указатель последуют в третьем и последнем томе данной публикации, которая, несомненно, является одним из самых значимых событий российской археографии последних лет.

\section{Заключение}

Во вступительном разделе коллективной монографии 2018 г. «Границы и маркеры социальной стратификации России XVII-XX вв.: векторы исследования» Д.А. Редин, проанализировав современную историографическую ситуацию, наметил круг актуальных задач «для конкретно-исторических исследований по социальной стратификации России Нового - Новейшего времени». Среди них - «выявление принципов и форм самоидентификации членов общества»; исследование «механизмов социального конструирования», в особенности «социального языка или, точнее сказать, языков эпохи»; поиск способов «перевода» «аутентичного языка прошлого на язык современных научных понятий»; «выявление причин и границ» изменчивости социальной стратификации; наконец, поиск «новой интегративной модели описания социальных процессов» на основе «признания многомерности и пластичности социальной структуры» ${ }^{55}$. Очевидно, что реализация этой исследовательской программы немыслима без введения в научный оборот новых источников. На этом пути исследователям социальной истории имперской России стоит приглядеться к опыту Франции и обратиться к комплексному анализу массового актового материала XVIII в., хранящегося в фондах крепостных учреждений, органов городского управления, а также родовых и монастырских собраний. Этот бесценный эмпирический материал, до сих пор плохо изученный, обладает исключительным потенциалом, так как он предоставляет социальному историку уникальную возможность для анализа реального взаимодействия представителей различных социальных групп в разнообразных жизненных ситуациях, таких как создание семей, купля и продажа имущества, ведение хозяйства, торговли и предпринимательства, строительство церквей и публичных зданий и многое другое.

Если актуальность обозначенной программы сомнений не вызывает, под вопросом остается стратегия освоения актового материала XVIII в. Проанализированные в обзоре публикации представляют три возможных пути введения в научный оборот российских частных сделок: 1) аналитическое полное описание больших комплексов актов с кратким указанием основных характеристик - дата, содержание сделки, имена и социальные характеристики контрагентов (описание А.В. Антонова); 2) выборочная публикация актов определенных разновидностей с полным воспроизведением текстов документов (публикации Н.В. Козловой и А.Ю. Прокофьевой); 3) 
комплексное монографическое исследование одного репрезентативного комплекса актов определенной разновидности (А.Б. Каменский). Какой из этих путей наиболее отвечает задачам осмысления истории России XVIII в. сквозь призму подходов и методов «новой социальной истории»? Чтобы ответить на этот вопрос, необходимо обратить внимание на достоинства и недостатки каждого из подходов. Описание позволяет относительно быстро сделать доступным для исследователей основное содержание больших и репрезентативных комплексов актовых материалов, но при этом не дает возможности ознакомиться с текстами документов. Такую возможность предоставляет публикация документов. Но публикация, в силу своей трудоемкости, накладывает на исследователей серьезные ограничения. Вместе с этим, многие акты, хранящиеся в одном комплексе (например, в одной крепостной книге), составлялись по одному формуляру, а это значит, что их полная публикация неизбежно будет дублировать значительную часть текстов документов. Монографическое исследование, выполненное по определенной программе, предоставляет читателю новое знание, но не дает ему возможности самому «окунуться в пучину документов» и задать источникам новые вопросы.

По всей видимости, на нынешнем этапе исследователям необходимо комбинировать эти три подхода, используя их взаимодополняемость. Описание (которое, очевидно, должно осуществляться силами исследовательских коллективов, а не отдельных лиц) позволило бы ознакомиться с содержанием крепостных книг и сделать обоснованный выбор документов, подлежащих полной публикации (в силу уникальности формуляра, содержания или состава контрагентов), а затем и их комплексному монографическому анализу. Заметим, что проблема комбинации описания и публикации актов серьезно обсуждалась уже в эпоху «золотого века» российской историографии, в конце XIX-начале XX вв., когда на повестке дня стояла задача введения в научный оборот неизданных средневековых актов. Не стоит ли сегодняшним историкам имперской России, отталкиваясь от тех вопросов, которые ставит перед ними «новая социальная история», вернуться к этой дискуссии и, усвоив богатый опыт российской дипломатики, перейти к разработке новой актовой археографии, ориентированной на введение в научной оборот российских актовых материалов XVIII в.?

1 - Публикация подготовлена в рамках Программы фундаментальных исследований НИУ ВШЭ в 2017 г.

2 - Michael Confino, "The soslovie (estate) paradigm: Reflections on some open questions," Cahiers du Monde russe, 49, 4 (2008): 681-704; Elise Kimerling Wirtschafter, "Social Categories in Russian Imperial History," Cahiers du Monde russe, 50, 1 (2009): 231-250; David L. Ransel, "Implicit Questions in Michael Confino's Essay: Corporate State and Vertical Relationships," Cahiers du Monde russe, 51, 2-3 (2010): 195-210; Robert E. Johnson, "Paradigms, categories, or fuzzy algorithms?" Cahiers du Monde russe, 51, 2-3 (2010): 461-466; Aleksander B. Kamenskii, "Do We Know The Composition of the $18^{\text {th }}$ Century Russian Society?" Cahiers du Monde russe, 55, 1 (2014): 135-148; Viktor E. Borisov, "The Tomilovs, Siberian Petty Noblemen: Career, Social Connections 
and Lifestyle at the Age of Transition from Tsardom to Empire," Cahiers du Monde Russe, 57, 2-3 (2016): 423-456. Краткие обзоры содержания этой дискуссии сделаны А.Б. Каменским (А.Б. Каменский. Россия в XVIII столетии. Общество и память. Исследования по сочиальной истории и исторической памяти (М.: Алтейя, 2017), 68-72), а затем Д.А. Рединым (Границы и маркеры сочиальной стратификации России XVII-XX вв.: векторы исследования (Санкт-Петербург: Алетейя, 2018), 78-85). Важно отметить, что дискуссия о категориях «класс» и «сословие» активно велась задолго до ее обсуждения на страницах Cahiers du monde russe. См., напр.: Люц Хэфнер, “«В России нет и никогда не было социальных классов»: монографии по социальной истории России Элизы Виртшафтер и Бориса Миронова,” $A b$ Imperio, 3-4, (2000): 413-432.

3 - См.: Wirtschafter, "Social Categories in Russian Imperial History," 248-249.

4 - «Because Russia was ruled as an assortment of socially specific groups, records were organized and preserved by institution and social position. As a consequence, scholars have found it difficult to integrate and analyze relations between people of different social statuses. The observable interactions, when they went beyond a single ministry, party, or social estate, were usually two-sided. Historians examine petitions from subordinates to superiors or look at court cases that pitted a person of one social estate against a person of another. But these limited and often conflictual documents tell less about what held Russian society together than about points of stress and possible rupture»: Ransel, "Implicit Questions in Michael Confino's Essay," 202-203.

5 - David L. Ransel, A Russian Merchant's Tale: The Life and Adventures of Ivan Alekseevich Tolchenov, Based on His Diary (Bloomington - Indianapolis: Indiana University Press, 2009).

6 - Н.Е. Копосов, Как думают историки (М.: Новое литературное обозрение, 2001), 71.

7 - Ibid., 71-72. Обстоятельный обзор социально-исторических исследований, основанных на французских нотариальных актах, см.: П.Ю. Уваров, Франция XVI века. Опьтт реконструкичи по нотариальным актам (М.: Наука, 2004), 24-70.

8 - Об институте площадных подьячих см.: Г.Ф. Злотников, «Подьячие Ивановской площади. К истории нотариата Московской Руси», in Сборник статей, посвященных А.С. Лаппо-Данилевскому (Петроград, 1916), 2-50; М.Б. Булгаков, «Псковские площадные подьячие в первой половине XVII в.», Псков, 20 (2004): 66-69; М.Р. Беделев. Исторические хроники нотариата Тульской губернии (М.: Фонд развития правовой культуры, 2008), 21-121.

9 -Подробнее о преобразованиях нотариального дела в петровской России см.: Г.Д. Капустина, «Записные книги Московской крепостной конторы как исторический источник (первая четверть XVIII в.)», in Проблемы источниковедения (М.: Издательство Академии наук СССР, 1959), т. 7, 217-232; А.В. Шалаев, И.М. Рыбакова, «Предисловие», in РГАДА, ф. 615, оn. 1. Ч. I. Крепостные книги местных учреждений XVI-XVIII вв. (М.: ЦГАДА), 1965, VII-IX; Л.М. Балакирева, «Создание Крепостной конторы при Юстиц-коллегии (1719 г.)», in Российское самодержавие и бюрократия: Сборник статей в честь Натальи Федоровнь Демидовой (М.: Древлехранилище, 2000), 202-218; А.В. Жуковская, «От поручения к учреждению: А.А. Курбатов и «крепостное дело» при Петре I», in Очерки феодальной России (М.: Альянс-Архео, 2009), вып. 13, 314-376; В.В. Захаров, «Преобразование нотариального дела в России на рубеже XVII-XVIII вв.: сравнительный анализ общеимперских и региональных начал», Историко-правовые проблемы: новый ракурс, 8 (2014): 22-38.

10 - Капустина, «Записные книги», 217-222.

11 - См.: А.В. Шалаев, И.М. Рыбакова, «Предисловие», in РГАДА (Российский государственный архив древних актов). Ф. 615, оп. 1. Ч. І. Крепостные книги местных учреждений XVI-XVIII вв. (М.: ЦГАДА), 1965, II.

12 - См.: РГАДА, ф. 285, оп. 1, кн. 235-820, 911-1056. 
13 - Точные подсчеты количества актов, скопированных в записные книги крепостных учреждений XVIII в. - дело будущего. Пока же мы можем лишь довольствоваться отрывочными сведениями. Г.Д. Капустина сообщает, что в «вотчинных» книгах Московской крепостной конторы петровского времени записывалось около 1000 земельных сделок в год. Количество актов в заемных книгах той же конторы также исчисляется тысячами: 3331 сделки в 1701 г., 5132 договора в 1702 г., 1003 акта в 1725 г. (См.: Капустина, «Записные книги», $234,248)$. Итак, счет ежегодно заключенных в Московской конторе договоров идет на десятки тысяч. Количество актов, регистрировавшихся в провинциальном городе, позволяет представить исследование Анны Жуковской. По ее подсчетам в Севске в петровские годы ежегодно в крепостные книги заносилось от 500 до 1000 актов (Anna Joukovskaia, "Unsalaried and Unfed: Town Clerks' Means of Survival in Southwest Russia under Peter I," Kritika: Explorations in Russian and Eurasian History, 14, 4 (2013): 729). Если мы допустим, что в одной записной книге столичного города в среднем насчитывается 1000 крепостей, а провинциального города - 100 сделок, получится, что во всех сохранившихся крепостных книгах XVIII в. содержится как минимум 4 млн. актов.

14 - См.: Е.И. Заозерская, Рабочая сила и классовая борьба на текстильных мануфактурах России в 20-60 г2. XVIII в. (М.: Издательство Академии наук СССР, 1960), 132-135; Г.Д. Капустина, «Из истории ремесленного ученичества в Москве в начале XVIII в.», in Bопросы сочиально-экономической истории и источниковедения периода феодализма в России (М.: Издательство Академии наук CССР, 1961); С.М. Троицкий, «Заемные книги крепостных контор как источник по истории крестьян в России середины XVIII века (по материалам Арзамасской крепостной конторы)», in Археографический ежегодник за 1962 г. (М.: Наука, 1963); Л.Н. Семенова, «Документы найма рабочих в первой четверти XVIII в.», in Вопросы историографии и источниковедения истории СССР, М.; Л.: Издательство Академии наук СССР, 1963); Г.Д. Капустина, «К истории хлебного рынка Москвы в начале XVIII в.», in Города феодальной России: сборник статей памяти Н.В. Устюгова (М.: Наука, 1966); Г.Д. Капустина, «Гужевой транспорт в Северной войне (По материалам Московской крепостной конторы начала XVIII в.)», in Вопросы военной истории России. XVII и первая половина XIX веков (М.: Наука, 1969); Н.Б. Голикова, «Ростовщичество в России начала XVIII в. и его некоторые особенности», in Проблемы генезиса капитализма. (М.: Наука, 1970), 242-290; Н.И. Павленко, «О ростовщичестве дворян в XVIII в. (к постановке вопроса)», in Дворянство и крепостной строй в России XVI-XVIII вв.: Сборник статей, посвященный памяти А.А. Новосельского (М.: Наука, 1975), 265-271; Н.Б. Голикова, «Кредит и его роль в деятельности русского купечества в начале XVIII в.», in Русский город (М.: Издательство Московского университета, 1979), вып. 2.

15 - См., напр.: Michelle Lamarche Marrese, A Woman's Kingdom: Noblewomen and the Control of Property in Russia, 1700-1861, (Ithaca - London: Cornell University Press, 2002) (Рус. пер.: М.Л. Маррезе, Бабье царство: дворянки и владение имуществом в России (1700-1861), М.: Новое литературное обозрение, 2009); О.Е. Кошелева, Люди Санкт-Петербургского острова Петровского времени (М.: ОГИ, 2004); М.В. Николаева, Частное строительство в Москве и Подмосковье. Первая четверть XVIII в. Подряднье записи (М.: Едиториал УРСС, 2004), т. I-II; Anna Joukovskaia, 'Unsalaried and Unfed: Town Clerks' Means of Survival in Southwest Russia under Peter I," Kritika: Explorations in Russian and Eurasian History, 14, 4 (2013): 715-739; Idem, "A Living Law: Divorce Contracts in Early Modern Russia," Kritika: Explorations in Russian and Eurasian History, 18, 4 (2017): 661-681.

16 - П.М. Строев, в 1837-1838 гг. впервые полностью просмотревший собрание грамот Коллегии экономии, в письме от 17 марта 1838 г. так описывал эту коллекцию: «Сии акты находились в Коллегии Економии и, по упразднении ея, сданы в Государственный Архив. Во времена оны ими обезпечивались обладание огромных имений архиерейских домов, монастырей, соборов и церквей; теперь 
это чистая собственность археологии, едва ли годная в иных отношениях. Наибольшая часть сих бумаг принадлежит XVII веку, особенно концу, довольно из XVI-го, сотни три-четыре из XV-го, древнее нет; много подлинников, несравненно более списков» (Н. Барсуков, Жизнь и труды П.М. Строева (СПб.: Типография В.С. Балашева, 1878), 321). Как мы видим, «патриарх» российской археографии даже не посчитал нужным упомянуть об актах XVIII в. С тех пор мало что изменилось. Сам А.В. Антонов называет эту коллекцию «крупнейшим собранием русских средневековых актов» (Т. 1. С. 3. Курсив мой. - E.A.).

17 - Городская семья ХVIII века. Семейно-правовые акть купцов и разночинцев Mосквbl, сост., вводная статья и комментарии Н.В. Козловой (М.: Издательство Московского университета), 2002.

18 - Городская семья ХVIII века, 9.

19 - История Москвы (М.: Издательство Академии наук СССР, 1953), т. 2, 62.

20 - В таких случаях Юстиц-коллегия проводила проверку, которая предполагала допросы завещателя (если он еще был жив), писца и свидетелей (См.: Городская семья XVIII века, 18, 34). Впрочем, вопрос о влиянии канцелярских служащих на содержание актов и социальные характеристики заслуживает специального изучения.

21 - А.И. Аксенов, Генеалогия московского купечества XVIII в. (Из истории формирования русской буржуазии) (М: Наука, 1988), 50.

22 - Городская семья ХVIII века, 521-523.

23 - Н.В. Козлова, «Духовные гостей Михаила Шорина (1711 г.) и Алексея Филатьева (1731 г.)», іп Очерки феодальной России (М.: УРСС), 2001, вып. 5, 200 203; Городская семья ХVIII века, 25, 124 - 127, 521 - 523.

24 - Ролан Мунье, обращаясь к анализу структуры французского общества по брачным контрактам, исходил из предположения, что «французы Старого порядка женились на ровне»; неравные браки, конечно, существовали, но «брачные контракты чутко реагировали на подобные отклонения от нормы соответствующим изменением состава приданого» (Уваров, Франция XVI века, 32).

25 - Городская семья ХИІІІ века, 339.

26 - Городская семья ХVIII века, 353-354.

27 - См.: Капустина, «Записные книги», 223-225.

28 - С.М. Каштанов, Русская дипломатика (М.: Высшая школа, 1988), 152.

29 - Книги протеста векселей использовались в исследованиях по истории торговли и финансов в России XVIII в.: George Munro, "Finance and credit in the Eighteenth-century Russian Economy," Jahrbücher für Geschichte Osteuropas, XLV, 4 (1987): 552-560; Idem, "The Role of the Veksel' in Russian capital Formation: A Preliminary Inquiry," in R.P. Bartlett, A.G. Cross and Karen Rasmussen, eds., Russia and the World of the Eighteenth Century (Columbus, OH: Slavica Publishers, Inc., 1988); Idem, "St. Petersburg's Bills of Exchange in the Russian Economy of the Eighteenth century," Research in Maritime history, 3 (December 1992): 99-113; В.Н. Захаров, «Роль западноевропейских купцов в развитии кредита в России XVIII в.», in Диффузия европейских инноваций в Российской империи: Материаль всероссийской научной конференции (Екатеринбург: Институт истории и археологии УрО РАН, 2009).

30 -А.Б. Каменский, Повседневность русских городских обывателей. Исторические анекдоты из провинциальной жизни XVIII века (М.: Российский государственный гуманитарный университет, 2006), 21.

31 - Cp.: Anna Joukovskaïa et Evgenii Akelev, «De cosaque à gentilhomme : Les Shagarov, une microhistoire de la mobilité sociale en Russie, $\mathrm{XVII}^{\mathrm{e}}-\mathrm{XVIII}{ }^{\mathrm{e}}$ siècles», Cahiers du Monde Russe, 57, 2-3 (2016): 467-476.

32 - См.: Каменский, Повседневность русских городских обывателей, 323

33 - Каменский, Повседневность русских городских обывателей, 110-111. 
34 - На проблему плохой сохранности архивов купеческих фамилий обратила внимание Н.В. Козлова (Городская семья XVIII века, 5). Впрочем, плохая сохранность оригиналов частных актов не только российская специфика (см., напр.: Уваров, Франция XVI века, 71).

35 - См.: В.Б. Кобрин, Власть и собственность в средневековой России (XV-XVI вв.) (М.: Мысль, 1985), 13.

36 -См.: В.В. Олевская, «Коллегия экономии духовных имений», in Государственность России : словарь-справочник (М.: Наука, 1999), кн. 2, 250-252.

37 - Барсуков, Жизнь и труды П.М. Строева, 322.

38 - Подробнее об описании грамот Коллегии экономии в 40-50-е гг. ХІХ в. см.: Л.И. Шохин, Московский архив Министерства Юстиции и русская историческая наука: Архивисты и историки во второй половине XIX-начале XX века (М.: Памятники исторической мысли, 1999), 48-59. См. также: Сборник Грамот Коллегии экономии (Петербург: Российская государственная академическая типография, 1922), т. 1, I-VIII.

39 - Д.М. Мейчик, «Грамоты и другие акты XIV-XV вв. Московского архива Министерства юстиции: их форма, содержание и значение в истории русского права», in Описание документов и бумаг, хранящихся в Московском архиве Министерства юстиции. (М.: Типография Л.Ф. Снигерева, 1884), т. 4, отд. 2, 1-160. Об этом описании см.: Шохин, Московский архив Министерства Юстиции, 74-75. 40 - Подробнее об этом см.: Шохин, Московский архив Министерства Юстиичи, 260-272; Idem, «О работе С.А. Шумакова над обзором Грамот Коллегии экономии», in C.А. Шумаков, Обзор «Грамот коллегии экономии» (М.: Древлехранилище, 2002), вып. 5: Материалы по Владимиру, Гороховцу, Мурому, Суздалю, Юрьев-Польскому и Вологде, 3-8.

41 - С.А. Шумаков, Обзор «Грамот коллегии экономии» (М.: Университетская типография, 1899), вып. 1: Обзор бежецких (1300-1767 гг.) и алатырских (1607-1761 гг.) актов; (М.: Университетская типография, 1900), вып. 2: Тексты и обзор белозерских актов (1395-1758 гг.); (М.: Синодальная типография, 1912), вып. 3: Верея, Волоколамск, Дмитров и Звенигород; (М.: Синодальная типография, 1917), вып. 4: Кострома «с товарищи» и Переславль-Залесский. В 2002 г. Л.И. Шохин опубликовал обнаруженный им незаконченный обзор Шумкова по Владимиру и другим городам: С.А. Шумаков, Обзор «Грамот коллегии экономии» (М.: Древлехранилище, 2002), вып. 5: Материалы по Владимиру, Гороховцу, Мурому, Суздалю, Юрьев-Польскому и Вологде.

42 - Сборник Грамот Коллегии экономии (Петербург: Российская государственная академическая типография, 1922), т. 1, Грамоты Двинского уезда. Петербург; (Л.: Издательство Академии наук СССР), т. 2. Грамоты Двинского, Кольского, Кеврольского, Кевроло-Меценского и Важского уездов. Подробнее об академическом проекте издания грамот Коллегии экономии см.: Сборник грамот Коллегии экономии, т. 1, I-XIII; А.И. Копанев, «Археографическая деятельность А.С. Лаппо-Данилевского в освещении С.Н. Валка», in Вспомогательные исторические дисииплины (Л.: Наука, 1978), т. IX, 81-89; Шохин, Московский архив Министерства Юстиции, 260-272.

43 - М.А. Дьяконов, «Городовые прикащики. Очерк из истории местного управления в Московском государстве XVI века», Журнал Министерства народного просвещения, CCCXXVII, (Январь 1900): 56.

44 -Российский государственный архив древних актов: Путеводитель, сост. Ю.М. Эскин (М.: Археографический центр, 1999), т. 4, 27.

45 - РГАДА, ф. 281, оп. 7, л. 82.

46 - Шумаков, Обзор «Грамот коллегии экономии», вып. 2, II-III.

47 - РГАДА, ф. 281, оп. 12, л. 8-8 об.

48 - Подробное описание документа см.: Шумаков, Обзор «Грамот коллегии экономии», вып. 4, 100. 
49 - Ibid., 108.

50 - Подробный пересказ акта см.: Шумаков, Обзор «Грамот коллегии экономии», вып. 5, 62-63.

51 - Подробный пересказ завещания см.: Шумаков, Обзор «Грамот коллегии экономии», вып. 4, 75-76.

52 - Ibid., 76.

53 - Подробный пересказ духовной см.: Ibid., 77-78.

54 - С.М. Каштанов рекомендует составлять предметно-терминологические указатели к изданиям актового материала, выделяя в рубрике «грамоты» названия разновидностей актов (См.: Каштанов С.М. Актовая археография (М. : Наука, 1998), 137-138).

55 - Д.А. Редин “«Новая социальная история»: в поисках исследовательских подходов и определения генерализирующих понятий," in Гранищы и маркеры соииальной стратификации России XVII-XX вв.: векторы исследования (Санкт-Петербург : Алетейя, 2018), 117-121.

\section{Evgenii Akelev}

National Research University Higher School of Economics,

Moscow 